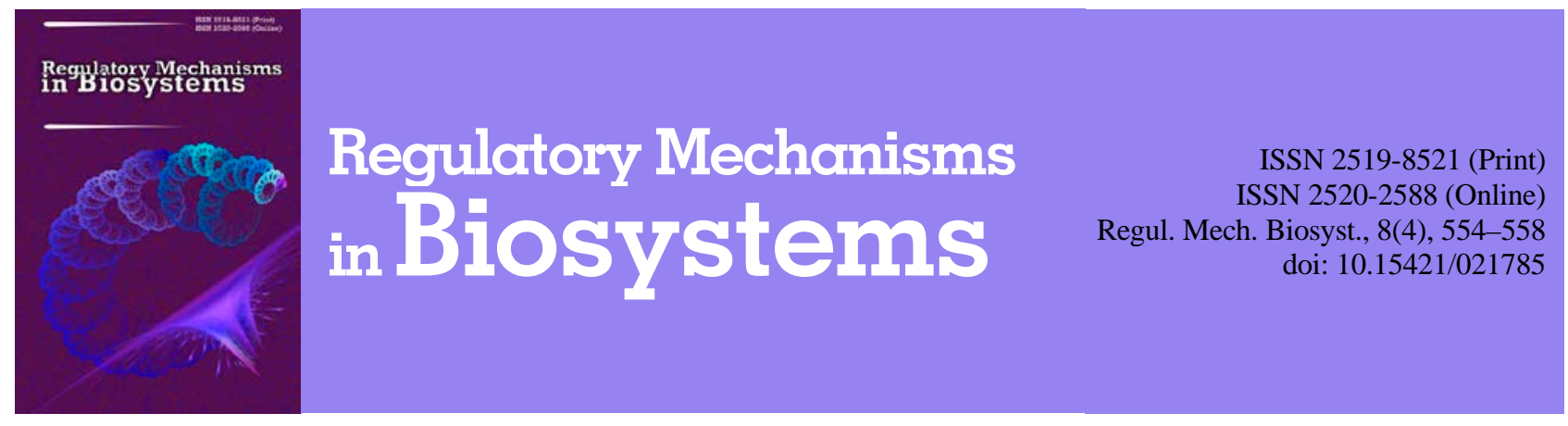

\title{
The thyroid status of a conditionally healthy adult population of Prydniprovia
}

\author{
I. Y. Arzhanov, M. R. Buniatov, G. A. Ushakova \\ Oles Honchar Dnipro National University, Dnipro, Ukraine
}

Article info

Received 24.10.2017

Received in revised form 12.11.2017

Accepted 17.11.2017

Oles Honchar Dnipro

National University,

Gagarin ave., 72,

Dnipro, 49010, Ukraine.

Tel.: +38-096-999-12-88

E-mail:ivanarzhanov@i.ua

\author{
Arzhanov, I. Y., Buniatov, M. R., \& Ushakova, G. A. (2017). The thyroid status of a conditionally healthy adult population of \\ Prydniprovia. Regulatory Mechanisms in Biosystems, 8(4), 554-558. doi:10.15421/021785
}

Pathologies of the thyroid gland are one of the most common diseases in endocrinology today. Hormones of the thyroid gland carry out hormonal regulation of the cell cycle, the physiological and post-traumatic repair of cells. The hormones of the thyroid gland secrete and enhance the oxidative processes and control the heat production, which can affect the mental state and the ability of the body to adapt to adverse environmental factors. In the case of a lack or almost complete absence of thyroid hormones, normal development and function of any functional system in the body is not possible. In the context of an increase in the incidence of thyroid gland pathology in Ukraine , this article presents an analysis of the thyroid status of the conditionally healthy population of Prydniprovia, related to age and gender. For the study, 120 patients of both sexes aged between 20 to 70 were selected. All patients were divided into 3 age groups of 40 people. Each age group was divided into 2 subgroups - male and female, with 20 people in each subgroup. Patients who, in the past and during the experiment, had no cases of thyroid gland disease were selected for accurate and reliable results. The study of thyroid status of the population showed that most of the adult and healthy population of Prydniprovia was not severely affected. All indicators were included in the age and gender limits of the norm, which are established by the preanalytical requirements of the independent laboratory Invitro (Dnipro, Ukraine). In women aged 50-70 years, there is an increased risk of hypothyroidism, which is confirmed by low levels of free thyroxine and triiodothyronine in the blood against the background of increased thyroid stimulating hormone and thyroglobulin levels. In the adult, conditionally healthy population of the Dnipro region aged between 20-70 years, the following correlation relations were observed between thyroid stimulating and thyroid hormones: at a younger age for men, the relationship between TSH and fT4 was -0.97 , for TSH and fT3 -0.96 , women also had a negative interdependence between these hormones ( -0.95 and -0.98 respectively). The age of the men who underwent the test did not change this dependence but in women after 50 years, the Pearson correlation coefficient decreased between the studied hormones TTG and fT4 and fT3 to -0.94 and -0.93 , respectively. Indicators of total thyroxine and total triiodothyronine in the blood serum are not indicative for determining the risk of hypothyroidism.

Keywords: thyroid gland; thyroid-stimulating hormone; thyroxine; triiodothyronine; thyroglobulin; parathyroid hormone; calcitonin

\section{Тиреоїдний статус умовно здорового дорослого населення Придніпров’я}

\author{
І. Ю. Аржанов, М. Р. Бунятов, Г. О. Ушакова \\ Дніпровський національний університет імені Олеся Гончара, Дніпро, Украӥна
}

Патології щитоподібної залози нині одні з найрозповсюдженіших ендокринологічних захворювань. Завдяки гормонам щитоподібної залози відбувається гормональна регуляція клітинного циклу, їх фізіологічна та посттравматична репарація. Гормони щитоподібної залози забезпечують і посилюють окисні процеси, контролюють теплопродукцію, здатні впливати на психічний стан і здатність організму адаптуватись до несприятливих факторів довкілля. У разі нестачі або майже повної відсутності тиреоїдних гормонів, нормальний розвиток і працездатність будь-якої функціональної системи організму не можливі. У зв'язку з підвищенням рівня захворюваності щитоподібної залози в Україні проаналізовано тиреоїдний статус умовно здорового населення Придніпров’я залежно від віку та статі. У більшості дорослих до 50 років здорових людей Придніпров'я серйозних порушень тиреоїдного статусу не спостерігали. Всі показники входили до меж вікових і статевих норм, установлених преаналітичними вимогами незалежної лабораторії Інвітро в Україні, м. Дніро. У жінок віком 50-70 років підвищений ризик розвитку гіпотиреозу, що підтверджуеться зниженим вмістом у крові вільного тироксину та трийодтироніну на тлі зростання конценрації тиреотропного гормону та тиреоглобуліну. Показники загального тироксину та загального трийодтироніну не показові для визначення ризику розвитку гіпотиреозу.

Ключові слова: щитоподібна залоза; тиреотропний гормон; тироксин; трийодтиронін; тиреоглобулін; паратгормон; кальцитонін

Вступ

Висока зацікавленість проблемою тиреоїдної патології останніми роками викликана їі різкою поширеністю серед населення
України. Одне з розповсюджених захворювань в ендокринологіїзахворювання саме щитоподібної залози, на них припадає 47,3\% усіх ендокринних хвороб. Головні причини, що зумовлюють зростання частоти тиреоїдних захворювань, - погіршення загальної 
екологічної обстановки, несприятливі фактори довкілля, що викликають різке зниження імунологічного захисту організму. Після Чорнобильської аварії з усіх органів ендокринної системи найсильніший радіаційний вплив припав саме на щитоподібну залозу через поглинання радіоізотопів йоду. Накопичення саме цих радіоізотопів йоду у щитоподібній залозі індукувало можливість розвитку патологічних процесів, таких як папілярна карцинома щитоподібної залози, не тільки у найближчі, а й у віддалені строки після опромінення, та зниження стійкості тиреоїдного статусу населення України (Selmansberger et al., 2015). Зі збілышенням кількості людей 3 онкологічною патологією щитоподібної залози в радіаційно забрудненій зоні спостерігається збільшення кількості пацієнтів з аутоімунними захворюваннями (Kimura et al., 2015).

За останні десять років кількість людей, яким діагностували гіпотиреоз, збільшилась на 38,9\%. Зниження рівня тиреотропного гормону можна вважати наслідком розвитку інших захворювань, пов'язаних із щитоподібною залозою, такими як тиреотоксикоз, рак щитоподібної залози, вузловий зоб (Horodynska and Bobyriova, 2016).

Щитоподібна залоза - один із найбільших непарних органів ендокринної секреції. Вона складається із двох часток, рудиментарної пірамідальної частки та перешийка. У людей вага здорової щитоподібної залози становить 15-20 г, а тироїдний об’єм - до 25 мл у чоловіків та 18 мл у жінок. Щитоподібна залоза характеризується високим темпом кровопостачання, який може досягати 5 мл/г/хв. Зовні щитоподібна залоза вкрита сполучнотканинною капсулою, від неї, безпосередньо, в сам орган відходять перегородки, що ділять щитоподібну залозу на часточки. Строма часточок складається 3 пухкої волокнистої сполучної тканини. В ній міститься густа сітка капілярів синусоїдного типу. Щитоподібна залоза складається з фолікул або тиреоцитів - структурно-функціональних одиниць, заповнених колоїдом, основний компонент якого - тиреоглобулін. Головна функція тиреоглобуліну - синтез тиреоїдних гормонів та їх депонування. У структуру щитоподібної залози входять Склітини, функція яких полягає у секреції кальцитоніну, який бере участь у регуляції кальцієвого обміну та виступає антагоністом паратгормону.

Завдяки тиреоїдним гормонам в організмі ссавців відбувається регуляція тканинного дихання та підтримання основних процесів обміну через стимуляцію рецепторів тиреоїдних гормонів, які, у свою чергу, змінюють експресію генів із необхідними метаболічними ефектами (Shin et al., 2014). На ембріональному етапі розвитку головна функція тиреоїдних гормонів - диференціація тканин (зокрема, нервової, опорно-рухової, серцево-судинної). Зміна рівня тиреоїдних гормонів, викликана дисфункцією щитоподібної залози, впливала на тиреоїдні рецептори, що викликало їх порушення у пухлинних клітинах, впливало на проліферацію клітин, диференціювання, виживання та інвазію різних новоутворень (Goemann et al., 2017).

У разі нестачі або майже повної відсутності тиреоїдних гормонів нормальний розвиток будь-якої функціональної системи в організмі не можливий (Tognini et al., 2014). Завдяки гормонам щитоподібної залози відбувається гормональна регуляція клітинного циклу, їх фізіологічна та посттравматична репарація. Завдяки регуляції експресії генів тиреоїдні гормони забезпечують реалізацію генотипу у фенотипі. Жодна спадкова інформація, одержана нащадками від предків, не зможе реалізуватись без тиреоїдних гормонів (Nilsson and Fagman, 2017). Гормони щитоподібної залози забезпечують і посилюють окисні процеси та контролюють теплопродукцію, здатні впливати на психічний стан і здатність організму адаптуватись до несприятливих факторів довкілля.

Тиреотропний гормон секретується в передній долі гіпофіза та стимулює в щитоподібній залозі синтез гормонів тироксину та трийодтироніну. За біохімічним походженням тиреотропний гормон - глікопротеїд, який складається $3 \alpha$ і $\beta$ субодиниць. Основні рецептори до тиреотропного гормону розташовані на поверхні епітеліальних клітин щитоподібної залози
(Bernal and Morte, 2013). Механізм синтезу тиреотропного гормону полягає в позитивному та негативному зворотному зв'язку 3 тиреоїдними гормонами. За підвищення концентрації тироксину та трийодтироніну рівень тиреотропного гормону знижується. Синтез тироксину відбувається з амінокислоти тирозину, яка йодується, та двох молекул дийодтирозину, від яких відщеплюється аланін. Після ферментативного розщеплення тиреоглобуліну тироксин потрапляє у кров, де з'єднується з білками плазми, такими як транстиретин, альбумін, тироксинзв'язувальний глобулін. У лабораторній діагностиці такі форми тироксину називаються загальним тироксином. У сироватці крові циркулюють два види тироксину: загальний та вільний. Їх головна відмінність полягає в тому, що загальний тироксин зв'язується з транспортними білками, вільний тироксин - майже ні. Концентрація загального тироксину в сироватці крові більша, ніж концентрація вільного тироксину.

Ще один високоактивний йодумісний гормон щитоподібної залози - трийодтиронін. На рівні з тироксином він бере участь у процесах регуляції та обміну, які відбуваються в організмі. Синтезується трийодтиронін із молекули тиреоглобуліну під час іiі протеолізу. Порівняно з тироксином, трийодтиронін здатний набагато легше проникати в клітини-мішені. В нормі співвідношення тироксину до трийодтироніну складає $1: 4$. Біологічна дія трийодтироніну аналогічна дії тироксину. Як і тироксин, у сироватці крові циркулює загальний трийодтиронін, з'єднаний із білками плазми та вільний. Зниження концентрації трийодтироніну спостерігається у людей не лише із захворюваннями щитоподібної залози, а й із серцево-судинними захворюваннями. Найчастіше рівень трийодтироніну різко знижується саме після операцій на серці (Marwali et al., 2013).

Попередник тироксину та трийодтироніну - глікопротеїн тиреоглобулін. Він продукується лише у щитоподібній залозі. Щитоподібна залоза складається 3 фолікул, у середині яких міститься колоїд, що складається переважно з тиреоглобуліну. Під час ферментативного розщеплення тиреоглобуліну відбувається його розпад на тирозин і атоми йоду. Тиреоглобулін може виступати маркером новоутворення або аутоімунних захворювань (Zheng and Sheila, 2014).

Також до гормонів щитоподібної залози відносять кальцитонін, що секретується в парафолікулярних (С-клітинах) клітинах щитоподібної залози та бере участь у регуляції обміну кальцію в організмі. Його основна функція - зниження концентрації кальцію у крові. За високої концентрації кальцитонін може також виступати онкомаркером медулярного раку щитоподібної залози (Valenciaga et al., 2017). Антагоністом кальцитоніну виступає паратиреоїдний гормон, який підвищує концентрацію кальцію крові (відомий як паратгормон), секретується головними клітинами паращитовидної залози. Паратгормон стимулює резорбцію кісткової тканини, тим самим посилюючи надходження кальцію в кров, знижує ниркову екскрецію кальцію, а також активує синтез вітаміну D. Визначення паратгормону важливе у клінічній діагностиці, оскільки завдяки ньому можна спрогнозувати розвиток гіперкальціємії у пацієнтів після операції на щитоподібній залозі (Bähler et al., 2017).

У зв'язку 3 підвищенням захворюваності щитоподібної залози в Україні мета цієї статті - оцінити тиреоїдний статус умовно здорового населення Придніпров’я залежно від віку та статі.

\section{Матеріал і методи досліджень}

Для проведення дослідження відібрано 120 пацієнтів віком 20-70 років чоловічої та жіночої статі. Усіх пацієнтів поділили на три вікові групи (по 40 чоловік). Кожна вікова група ділилась ще на дві підгрупи: чоловічу та жіночу (по 20 чоловік у кожній). Першу групу (молодого віку) склали пацієнти 20-30 років, другу (середнього віку) - 31-50, третю (похилого віку) - 5170 років. Для отримання точних результатів, відбирали пацієнтів, які в минулому та під час проведення експерименту не мали випадків захворювань щитоподібної залози. Відбирання венозної 
крові та отримання сироватки крові проводили у стандартних умовах клініко-діагностичної лабораторії Invitro (м. Дніпро). Усі зразки взяті $з$ добровільної згоди пацієнтів.

Для визначення тиреоїдного статусу дорослого населення досліджували такі показники: тиреотропний гормон (ТТГ), вільний і загальний тироксин (в $\left.\mathrm{T}_{4} \mathrm{Ta}_{3} \mathrm{~T}_{4}\right)$, вільний $\mathrm{i}$ загальний трийодтиронін (в $\mathrm{T}_{3}$ та $3 \mathrm{~T}_{3}$ ), тиреоглобулін (ТГ), інтактний паратгормон (іПГ), кальцитонін (КЦ). Використовували сироватку пацієнтів. Усі дослідження проведено на авторизованому, високочутливому твердофазному хемілюмінесцентному імуноферментному аналізаторі Siemens Immulite 2000XРі (США). До складу тест-систем входили набори 3 твердими (скляні кульки, покриті моноклональними мишачими антитілами до $\mathrm{TT \Gamma ,} \mathrm{BT}_{4}, \mathrm{BT}_{3}, \mathrm{~T}_{3}, \mathrm{~T}_{4}, \mathrm{iПГ,} \mathrm{КЦ} \mathrm{або} \mathrm{антилігандом} \mathrm{для} \mathrm{ТГ)} \mathrm{i}$ рідкими кон'югатами 3 поліклональними антитілами до ТТГ, $\mathrm{BT}_{4}, \mathrm{BT}_{3}, \mathrm{~T}_{3}, \mathrm{~T}_{4}$, лужної фосфатази у буфері з консервантом або мічені лігандом моноклональні мишачі антитіла до іПГ, КЦ, ТГ і кон’югати лужної фосфатази з поліклональними антитілами до іПГ, КЦ та ТГ вівці (Siemens, Англія). Схема проведення дослідження для всіх показників стандартна, згідно з інструкцією виробника наборів.

Досліджені параметри наведені як середнє значення вибірки та стандартне відхилення $(\mathrm{x} \pm \mathrm{SD})$. Показники норми враховували згідно з преаналітичними вимогами незалежної лабораторії Інвітро. Статистичну обробку результатів проведено у програмі Statwin, використовуючи однофакторний дисперсійний аналіз (ANOVA). Вірогідним вважали відмінності за $\mathrm{P}<0,05$.

\section{Результати}

Найвищий рівень тиреотропного гормону реєстрували в чоловіків віком 20-30 років $(2,74 \pm 1,47$ мОд./л), найнижчий у чоловіків віком $31-50$ років (2,56 $\pm 1,26$ мОд./л, рис. 1$)$. У жінок спостерігали іншу динаміку змін кількості тиреотропного гормону у крові протягом старіння: найнижчий рівень - у жінок віком 20-30 років (2,30 土 1,27 мОд./л), найвищий - у 5170-річних $(5,31 \pm 2,87$ мОд./л) за референтного нормального рівня - 0,4-4,0 мОд./л.

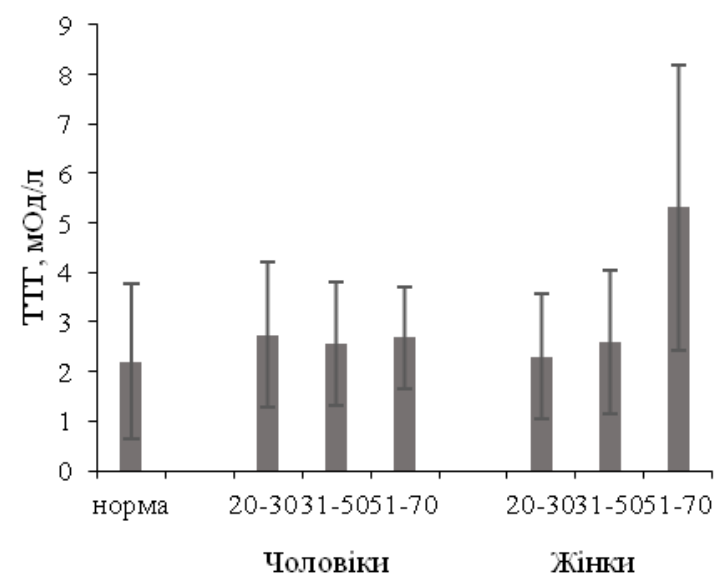

Рис. 1. Вміст тиреотропного гормону в крові чоловіків та жінок 20-70 років $(\mathrm{x} \pm \mathrm{SD}, \mathrm{n}=20)$

Рівень вільного тироксину як у чоловіків, так і у жінок віком 20-50 років, які не мали будь-яких ускладнень щодо щитоподібної залози, коливався в межах референтної норми (1319 пмоль/л), але після 50 років визначено статистично не значиму, але спрямовану тенденцію до зниження рівня цього гормону, особливо у жінок (до $11,7 \pm 2,87$ пмоль/л, рис. 2).

Показники загального тироксину, який відображає загальну концентрацію в крові вільного та зв'язаного з білками гормону умовно здорового населення Придніпров'я, вірогідно не змінювалися протягом дорослого життя як у чоловіків, так i жінок (80-110 нмоль/л, рис. 3).

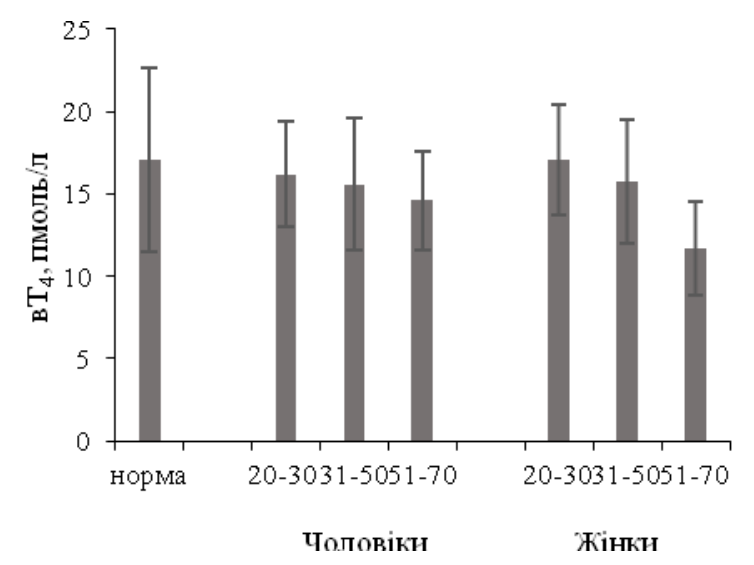

Рис. 2. Вміст вільного тироксину в крові чоловіків та жінок 20-70 років $(\mathrm{x} \pm \mathrm{SD}, \mathrm{n}=20)$

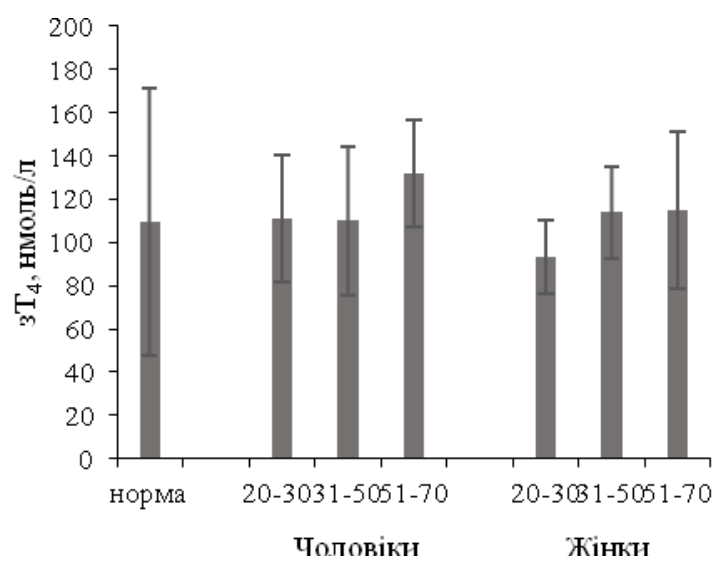

Рис. 3. Вміст загального тироксину в крові чоловіків та жінок 20-70 років $(\mathrm{x} \pm \mathrm{SD}, \mathrm{n}=20)$

Концентрація вільного трийодтироніну в дорослої чоловічої частини населення зберігалась у межах референтної норми (4,2-5,1 пмоль/л, рис. 4). У жінок спостерігали дещо іншу ситуацію. У 20-50 років рівень трийодтироніну перебував у межах норми $(4,8 \pm 1,5$ пмоль/л), а починаючи з 50 років знижувався (до 2,6 $\pm 1,2$ пмоль/л).

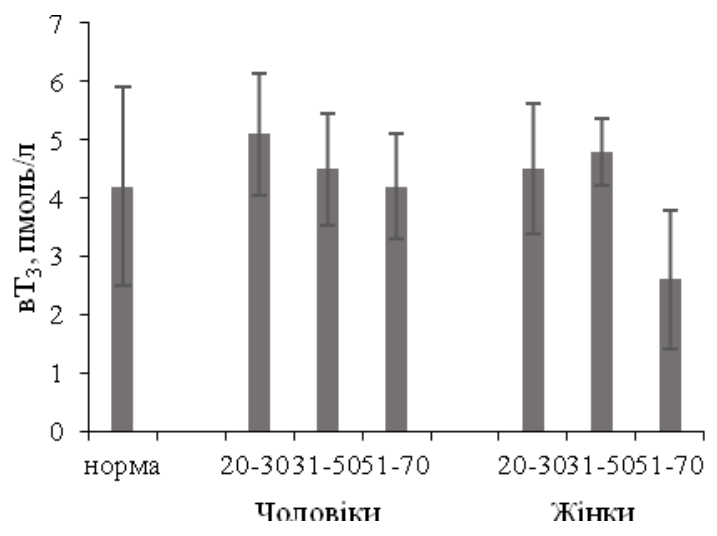

Рис. 4. Вміст вільного трийодтироніну в крові чоловіків та жінок 20-70 років $(\mathrm{x} \pm \mathrm{SD}, \mathrm{n}=20)$

Концентрація загального трийодтироніну набагато нижча за концентрацію загального тироксину, однак вона - один 3 обов'язкових показників тиреоїдного статусу населення. Рівень загального трийодтироніну у дорослого населення Придніпров'я віком 20-70 років коливався від 1,9 до 2,2 нмоль/л в межах норми (рис. 5). 


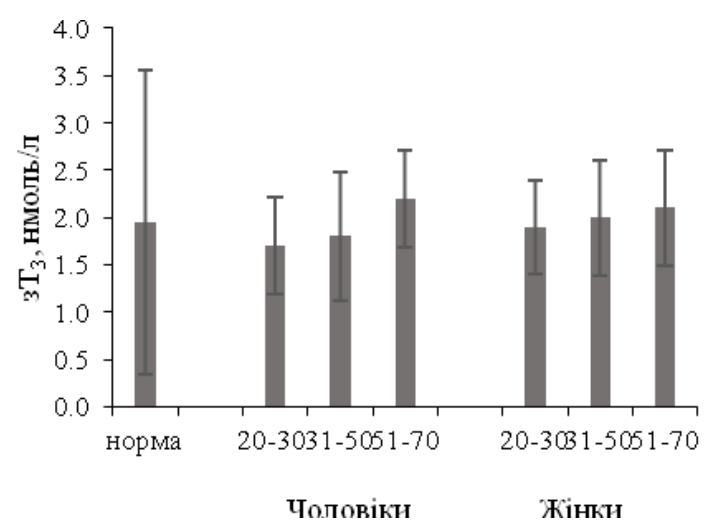

Рис. 5. Вміст загального трийодтироніну у крові чоловіків та жінок 20-70 років $(\mathrm{x} \pm \mathrm{SD}, \mathrm{n}=20)$

Тироксин та трийодтиронін - кінцеві форми гормонів щитоподібної залози, які утворюються з тиреоглобуліну. Частіше аналіз ТГ застосовують для діагностики двох видів пухлин залози (папілярного та фолікулярного раку), особливо для контролю за успішністю лікування та раннього виявлення метастазів у лімфатичних вузлах та інших органах (легенях, кістках, головному мозку). В умовно здорової чоловічої частини населення концентрація тиреоглобудіну впродовж $20-70$ років життя майже не змінюється $(9,2-11,3$ нг/мл, рис. 6). У жінок 50-70 років відмічено тенденцію до збільшення продукції тиреоглобуліну удвічі, але цей показник залишився в межах референтної норми.

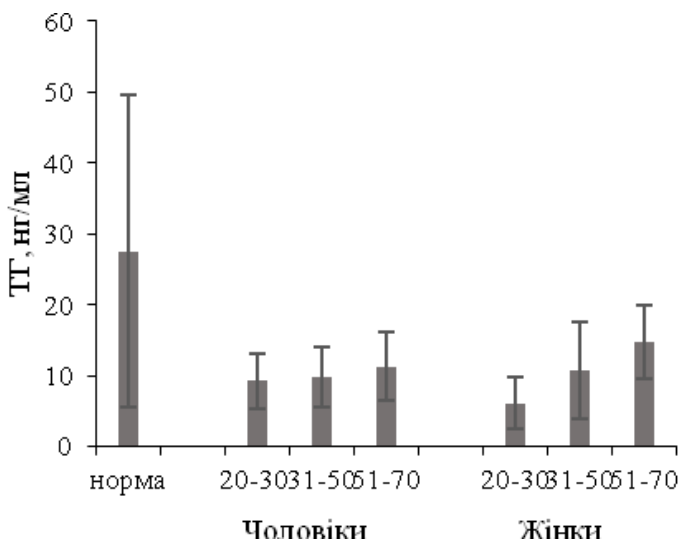

Pис. 6. Вміст тиреоглобуліну в крові чоловіків та жінок 20-70 років $(\mathrm{x} \pm \mathrm{SD}, \mathrm{n}=20)$

Щитоподібна залоза продукує інтактний паратгормон, який регулює підвищення концентрації кальцію в плазмі крові. У ході дослідження виявлено незмінний рівень інтактного паратгормону в умовно здорового дорослого населення віком 20-70 років як у чоловіків, так і у жінок: в межах 3,2-5,0 пмоль/л (рис. 7).

Антагоніст інтактного паратгормону - кальцитонін; його основна функція - зниження рівня кальцію в плазмі крові. У чоловіків молодого віку зареєстровано низький рівень кальцитоніну $-2,0 \pm 1,4$ пг/мл (P < 0,01), який стабілізується після 30 років і суттєво не змінюється до 70 років (рис. 8).

Нормальна концентрація кальцитоніну в чоловіків будьякого віку складала до 8,4 пг/мл. У жінок 20-70 років рівень кальцитоніну зберігався в межах референтної норми.

\section{Обговорення}

Отримані результати вказують на стабільний тиреоїдний статус в умовно здорового населення Придніпров'я 20-50 років. У чоловіків 20-70 років та жінок до 50 років рівень тиреотропного гормону, тиреоглобуліну, вільного тироксину та три- йодтироніну залишався в межах норми. У жінок після 50 років спостерігали тенденцію до високого ризику розвитку гіпотиреозу, що, скоріше за все, пов'язано з віковими змінами загального гормонального статусу жінок (Cooper and Laurberg, 2013). У жінок після 50 років концентрація вільного тироксину та трийодтироніну мала тенденцію до зменшення на тлі збільшеної продукції тиреотропного гормону та тиреоглобуліну.

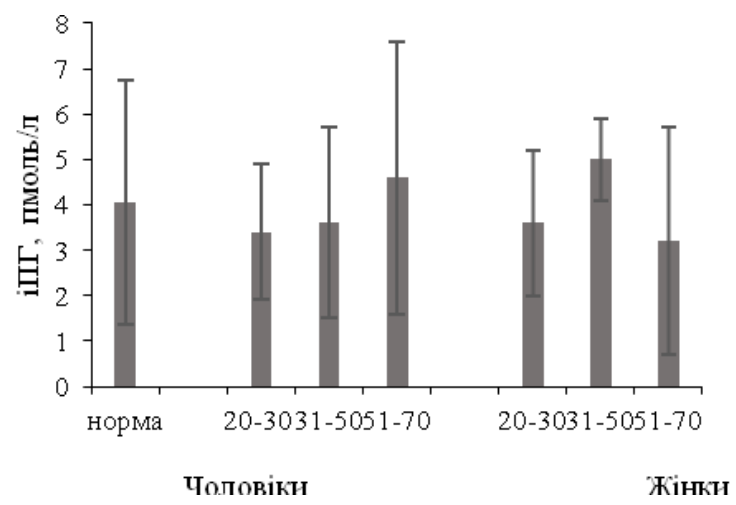

Рис. 7. Вміст інтактного паратгормону в крові чоловіків та жінок 20-70 років $(\mathrm{x} \pm \mathrm{SD}, \mathrm{n}=20)$

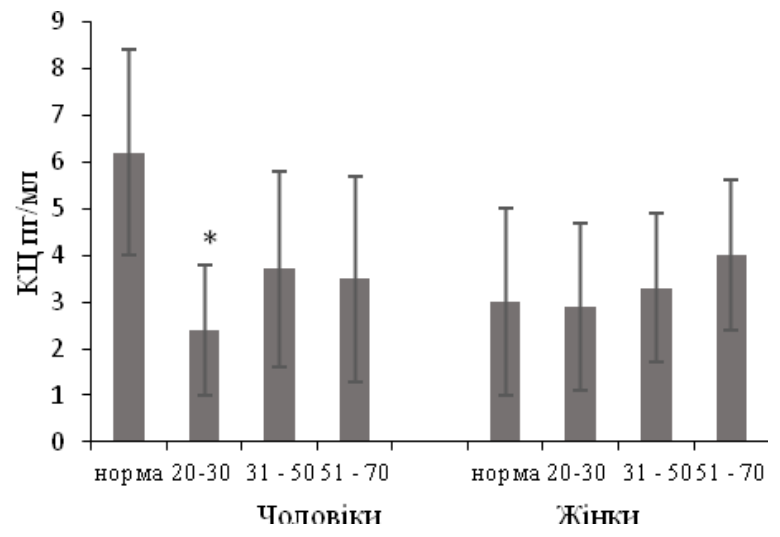

Рис. 8. Вміст кальцитоніну в крові чоловіків та жінок 20-70 років $\left(\mathrm{x} \pm \mathrm{SD} ; \mathrm{n}=20{ }^{*}-\mathrm{P}<0,01\right)$

Синтез тереоїдних гормонів тироксину та трийодтироніну прямо залежить від тиреотропного гормону, який секретується гіпофізом. Такий зв'язок характеризується від'ємним кореляційним співвідношенням, оскільки тиреотропний гормон реагує на концентрацію тироксину та трийодтироніну в крові. Якщо в організмі низький рівень тиреоїдних гормонів, для підвищення їх концентрації стимулюється секреція тиреотропного гормону, і його концентрація в крові підвищується. У дорослого умовно здорового населення Придніпров'я 20-70 років спостерігали такі кореляційні зв'зки між тиреотропним та тиреоїдними гормонами: у молодому віці для чоловіків зв'язок між ТТГ та в $\mathrm{T}_{4}$ становив $-0,97(\mathrm{P}<0,001)$, для ТТГ та в $\mathrm{T}_{3}-$ 0,96 (Р < 0,001). У жінок також установлено від'ємну взаємозалежність між цими гормонами: $-0,95(\mathrm{P}<0,005)$ та $-0,98(\mathrm{P}<$ 0,001), відповідно. 3 віком у чоловіків, що проходили обстеження, ця залежність не змінювалася, але у жінок після 50 років зареєстровано зниження кореляційного коефіцієнта Пірсона між досліджуваними гормонами ТТГ та в $\mathrm{T}_{4}$ і в $\mathrm{T}_{3}$ до $-0,94$ (P < $0,01)$ та $-0,93(\mathrm{P}<0,01)$, відповідно.

Останні дослідження свідчать, що розвиток гіпотиреозу в літніх людей може нести негативні наслідки для організму: атеросклероз, гіперхолестеринемія та цереброваскулярні захворювання. Клінічний гіпотиреоз поширений більше ніж у $20 \%$ пацієнтів із цереброваскулярними захворюваннями, але не 3 нейропатологією типу хвороби Альцгеймера (Brenowitz et al., 2017). Розвиток захворювань щитоподібної залози тісно пов’я- 
заний із захворюваннями метаболічного обміну. Традиційно гормони щитоподібної залози використовують для корекції функцій щитоподібної системи. Проте вони характеризуються багатьма побічними ефектами, такими як їх негативний вплив на серцево-судинну систему, а також здатність тиреоїдних гормонів підвищувати інсулінорезистентність і порушувати функцію, що виробляє інсулін підшлункової залози, тим самим загострюючи діабетичну патологію (Shpakov, 2017). Порушення функцій щитоподібної залози може викликати зміни ліпідного обміну. Розвиток гіпотиреозу може спричинити ожиріння (Poddar et al., 2017).

У дорослому мозку нервові стовбурові клітини, розташовані в субвентрикулярній зоні, розвиваються як у нейрональні, так i гліальні клітини. Гормони щитоподібної залози регулюють диференціацію дорослих нервових стовбурових клітин у бік нейронального фенотипу та відіграють важливу роль у метаболізмі мітохондрій. Тривалий гіпотиреоз здатен зменшити не тільки кількість нейробластів, а й їх мітохондріальну активність (Gothié et al., 2017), що, у свою чергу, може провокувати когнітивні порушення.

Тиреоглобулін - одна зі складових, необхідна для синтезу гормонів щитоподібної залози: тироксину та трийодтироніну. Папілярна карцинома щитоподібної залози становить близько $80 \%$ випадків захворювання на рак щитоподібної залози. Регулярне спостереження за сироватковим тиреоглобуліном і медичною візуалізацією - поточна практика для контролю прогресування захворювання пацієнтів (Lin et al., 2016). Тиреоглобулін використовують як надійний прогностичний післяопераційний маркер диференційованого раку щитоподібної залози (папілярний та фолікулярний патгістологічні типи) та хвороби Грейвса (Аоуата et al., 2017). Високий рівень тиреоглобуліну асоціюється з наявністю захворювання щитоподібної залози у популяціях, де екологічні фактори впливають на іонізуючу радіацію, і на людей, які живуть у регіонах 3 ендемічним слабким і середнім вмістом йоду у воді (Peters et al., 2017).

Гормони кальцитонін та інтактний паратгормон між собою також пов'язані. Кальцитонін відповідає в організмі за зниження рівня кальцію, а його біологічне значення в кальцієвому гомеостазі не дуже значне. Проте він може виступати онкомаркером медулярного раку щитоподібної залози, який розвивається у парафолікулярних клітинах і продукує кальцитонін (Verburg et al., 2013). На відміну від кальцитоніну, інтактний паратгормон підвищує рівень кальцію в організмі. Нормальна секреція інтактного паратгормону важлива для дітей і людей похилого віку, оскільки за його низької концентрації або повної відсутності можуть розвиватися різні захворювання пов'язані з опорно-руховою системою. Особливо небезпечне у літніх людей таке захворювання як остеопороз (Cho et al., 2017). У дорослого умовно здорового населення Придніпров'я рівень інтактного паратгормону коливався в межах норми, проте у чоловіків віком 20-70 років та у жінок $20-50$ років рівень паратгормону з віком підвищувався, на відміну від жінок віком 51-70 років, для яких реєстрували зниження рівня паратгормону. Такі особливості, скоріше за все, пов'язані саме 3 віковими та гормональними особливостями. Незважаючи на те, що нормальний рівень кальцитоніну у чоловіків та жінок різний, значних відхилень від референтних показників не зареєстровано.

\section{Висновки}

У більшості дорослих 20-50 років у Придніпров”ї серйозних порушень тиреоїдного статусу не виявлено. Всі показники входили у вікові та статеві межі норми, встановлені преаналітичними вимогами незалежної лабораторії Інвітро (Дніпро, Україна). У жінок 50-70 років підвищений ризик розвитку гіпотиреозу, підтверджений зниженим вмістом у крові вільного тироксину та трийодтироніну на тлі зростання концентрації тиреотропного гормону та тиреоглобуліну. Показники загального тироксину та загального трийодтироніну не показові для визначення ризику розвитку гіпотиреозу.

\section{References}

Aoyama, M., Takizawa, H., Tsuboi, M., Nakagawa, Y., \& Tangoku, A. (2017). A case of metastatic follicular thyroid carcinoma complicated with Graves' disease after total thyroidectomy. Endocrine Journal, 17, 1-5.

Bähler, S., Müller, W., Linder, T., Frotzler, A., Fischli, S., Aqtashi, B., Elmas, F., \& Nader, A. (2017). Intraoperative parathyroid hormone measurement is the best predictor of postoperative symptomatic hypocalcemia. HNO, 65(9), 1-7.

Bernal, J., \& Morte, B. (2013). Thyroid hormone receptor activity in the absence of ligand: Physiological and developmental implications. Biochimica et Biophysica Acta, 1830(7), 3893-3899.

Brenowitz, W. D., Han, F., Kukull, W. A., \& Nelson, P. T. (2017). Treated hypothyroidism is associated with cerebrovascular disease but not Alzheimer's disease pathology in older adults. Neurobiology of Aging, 3(62), 64-71.

Cho, M., Han, S., Kim, H., Kim, K. S., \& Hahn, S. K. (2017). Hyaluronate-parathyroid hormone peptide conjugate for transdermal treatment of osteoporosis. Journal of Biomaterials Science, Polymer Edition, 28(19), 1-21.

Cooper, D. S., \& Laurberg, P. (2013). Hyperthyroidism in pregnancy. The Lancet Diabetes and Endocrinology, 1(3), 238-249.

Goemann, I. M., Romitti, M., Meyer, E. L. S., Wajner, S. M., \& Maia, A. L. (2017). Role of thyroid hormones in the neoplastic process: An overview. Endocrine Related Cancer, 24(11), 367-385.

Gothié, J. D., Sébillot, A., Luongo, C., Legendre, M., Nguyen, V. C., LeBlay, K., Perret-Jeanneret, M., Remaud, S., \& Demeneix, B. A. (2017). Adult neural stem cell fate is determined by thyroid hormone activation of mitochondrial metabolism. Molecular Metabolism, 6(11), 1551-1561.

Horodynska, O. Y., \& Bobyriova, L. Y. (2016). Prohnostychna kharakterystyka poshyrenosti hipotyreozu v Poltavs'kiy oblasti ta v Ukrayini v tsilomu za umovy odnoho defitsytu. [Prognostic characteristics of hypothyroidism prevalence in the Poltava region and in Ukraine under conditions of iodine deficiency]. Mezdunarodnyj Endocrynologychesky Jurnal, 74, 44-49.

Kimura, Y., Hayashida, N., Takahashi, J., Rafalsky, R., Saiko, A., Gutevich, A., Chomiy, S., Kudo, T., \& Takamura, N. (2016). Evaluation of thyroid antibodies and benign disease prevalence among young adults exposed to ${ }^{131}$ I more than 25 years after the accident at the Chemobyl Nuclear Power Plant. PeerJ, 4, 1-12.

Lin, H. C., Liou, M. J., Hsu, H. L., Hsieh, J. C., Chen, Y. A., Tseng, C. P., \& Lin, J. D. (2016). Combined analysis of circulating epithelial cells and serum thyroglobulin for distinguishing disease status of the patients with papillary thyroid carcinoma. Oncotarget, 7(13), 17242-17253.

Marwali, E. M., Boom, C. E., Sakidjan, I., Santoso, A., Fakhri, D., Kartini, A., Kekalih, A., Schwartz, S. M., \& Haas, N. A. (2013). Oral triiodothyronine normalizes triiodothyronine levels after surgery for pediatric congenital heart disease. Pediatric Critical Care Medicine, 14(7), 701-708.

Nilsson, M., \& Fagman, H. (2017). Development of the thyroid gland. Development, 144(12), 2123-2140.

Peters, K. O., Tronko, M., Hatch, M., Oliynyk, V., Terekhova, G., Pfeiffer, R. M., Shpak, V. M., McConnell, R. J., Drozdovitch, V., Little, M. P., Zablotska, L. B., Mabuchi, K., Brenner, A. V., \& Cahoon, E. K. (2017). Factors associated with serum thyroglobulinin a Ukrainian cohort exposed to iodine-131 from the accident at the Chernobyl Nuclear Plant. Environmental Research. 156, 801-809.

Poddar, M., Chetty, Y., \& Chetty, V. T. (2017). How does obesity affect the endocrine system? A narrative review. Clinical Obesity, 7(3), 136-144.

Selmansberger, M., Braselmann, H., Hess, J., Bogdanova, T., Abend, M., Tronko, M., Brenner, A., Zitzelsberger, H., \& Unger, K. (2015). Genomic copy number analysis of Chernobyl papillary thyroid carcinoma in the Ukrainian American Cohort. Carcinogenesis, 36(11), 1381-1387.

Shin, J. A., Mo, E., Kim, E. S., Moon, S. D., \& Han, F. H. (2014). Association between lower normal free thyroxine concentrations and obesity phenotype in healthy euthyroid subjects. International Journal of Endocrinology, $104318,1-8$.

Shpakov, A. O. (2017). Farmakologicheskiye podkhody dlya korrektsii disfunktsiy shchitovidnoy zhelezy v usloviyakh sakharnogo diabeta [Pharmacological approaches for correction of thyroid dysfunctionsin diabet esme]llitus Biomeditsinskaīa Khimiøæ(3), 219-231 (in Russian).

Tognini, S., Pasqualetti, G., Calsolaro, V., Polini, A., \& Monzani, F. (2014). Cognitive function and quality of life in mild thyroid hormone deficiency. Recent Patents on Endocrine, Metabolic \& Immune Drug Discovery, 8(2), 124-134.

Valenciaga, A., Grubbs., E. G., Porter, K., Wakely, P. E. Jr., Williams, M. D., Cote, G. J., Vasko, V. V., Saji, M., \& Ringel, M. D. (2017). Reduced retinoblastoma protein expression is associated with decreased patient survival in medullary thyroid cancer. Thyroid, 27.

Verburg, F. A., Reiners, C., Grelle, I., Barth, H., Fassnacht, M., \& Luster, M. (2013). Calcium stimulate dcalcitonin measurement: A procedural proposal. Experimental and Clinical Endocrinology \& Diabetes. 121(5), 318-320.

Zheng, F. M., \& Sheila, A. S. (2014). Thyroglobulin as a biomarker of iodine deficiency. Thyroid, 24(8), 1195-1209. 